\title{
A REFORMED NATURAL THEOLOGY?
}

\section{SEBASTIAN REHNMAN}

University of Stavanger

\begin{abstract}
This paper aims to counter the recent opinion that there is a peculiar epistemology in the reformed Church which made it negative to natural theology. First it is shown that there was an early and unanimous adoption of natural theology as the culmination of physics and the beginning of metaphysics by sixteenth and seventeenth century philosophers of good standing in the reformed Church. Second it is argued that natural theology cannot be based on revelation, should not assume a peculiar analysis of knowledge and must not pass over demonstration.
\end{abstract}

\section{INTRODUCTION}

The title of this paper admittedly contains some confusion. But recently a notion of an allegedly pessimistic natural theology based on (purportedly) revealed principles of the reformed Church has been circulating among philosophers. ${ }^{1}$ This notion is confused, since if the principles of natural theology are supernatural, then either it is not natural theology or it is circular. There may be a natural theology by philosophers in the reformed Church, but not a natural theology based on the doctrines of the reformed Church. It is moreover confused to characterise such a natural theology as pessimistic in contrast to an allegedly optimistic mediaeval one. For thinkers such as Anselm, Aquinas, Scotus and Suarez did not maintain the sufficiency of natural theology for Christian faith. For

all the important Catholic mediaeval thinkers held to the conviction that divine revelation is absolutely necessary for us to flourish as human 
beings and that, as far as ultimate metaphysical and moral questions are concerned, we remain in an utterly perilous state of ignorance without it. ${ }^{2}$

It is simply misleading to characterise natural theology in the reformed tradition in contrast with natural theology in the mediaeval tradition.

The recent opinion can be traced to 1980. Then Alvin Plantinga made the historically outrageous claim that the 'attitude' of the reformed Church towards natural theology 'ranged from tepid endorsement, through indifference, to suspicion, hostility and outright accusation of blasphemy. ${ }^{3} \mathrm{He}$ could do this only by ignoring authoritative confessions of faith as well as acknowledged works of natural theology written by members in good standing of the reformed Church from the sixteenth century to the nineteenth century, ${ }^{4}$ and by merely following the two modern theologians Herman Bavinck and Karl Barth, through whom he culled a few citations from John Calvin. ${ }^{5}$ Plantinga's descriptions of natural theology in general and of Calvin in particular have been dismissed both historically and philosophically. ${ }^{6}$ Still, Alvin Plantinga, Nicholas Wolterstorff, and several contributors to standard reference works continue to repeat the claim that the reformed tradition is negative towards natural theology. ${ }^{7}$

Thus there is a need to revisit the notion of natural theology in the reformed Church, and Michael Sudduth has recently attempted to do so in a monograph along both historical and philosophical lines. ${ }^{8}$ The aim of the historical part is to rebut the misconception caused by Plantinga. Sudduth's historical survey shows that the reformed Church unanimously endorsed natural theology early on, but that objections to natural theology within the reformed Church arose in early twentieth century Dutch and Barthian neo-orthodoxy. He appears to identify two reasons for this opposition. First, these theologians objected to the 'Cartesian and Wolffian' view that natural theology provides the necessary basis for supernatural or revealed theology. ${ }^{9}$ Second, they opposed natural theology because they adopted Hume's and Kant's epistemologies. ${ }^{10}$ Sudduth concludes that 'the "Reformed objection" to natural theology, as characterized by' Plantinga and Wolterstorff, 'simply did not exist before they invented it."'11 The aim of the philosophical part is next to provide a conceptual framework for the evaluation of objections as well as the clarification and defence of natural theology within the reformed Church. Sudduth distinguishes three objections: intuition is the only source of natural knowledge of God, all demonstrations about God are invalid, 
and sin makes people unable to reason about God. These are all found to be overstatements. The focus of the book is then a 'set of conceptual distinctions. ${ }^{12}$ First Sudduth infers a distinction between two kinds of natural theology. The former arises 'spontaneously' in humans and not 'as the result of any conscious process of reasoning', while the latter is the result of 'philosophical argument'; the latter is grounded in and develops the former. ${ }^{13}$ Second, two 'functions', 'models' or 'uses' of philosophical arguments about God are distinguished. One is internal and the other 'external to dogmatic', supernatural or revealed theology. ${ }^{14}$ Third (and closely related) is the distinction between the project and function of philosophical arguments about God, ${ }^{15}$ namely the difference between that there is natural theology and what natural theology is. Lastly, there is a distinction between model-specific objections and project objections to natural theology; ${ }^{16}$ that is, between opposition to some model(s) of natural theology and to the entire project of natural theology. ${ }^{17}$

Unfortunately there are both historical and epistemological problems in this assessment. In the first and historical part of this paper I argue for the correct identification of natural theology in the reformed Church, namely as the early, unanimous and continuous commitment to natural theology at the end of physics and the beginning of metaphysics - apart from a negligible minority of neo-orthodox theologians who opposed it on the authority of Hume and Kant. ${ }^{18}$ In the second and epistemological part I maintain the distinction between natural and supernatural theology, question the development of natural theology within the analysis of knowledge as justified true belief, and defend demonstrative natural theology. ${ }^{19}$

\section{NATURAL THEOLOGY IN THE REFORMED CHURCH HISTORICALLY REVISITED}

One of the major problems with the recent opinion is that it is not historically informed. Although Sudduth's historical argument is better than most, there are several problems with it. The discussion about natural theology in the reformed Church will continue to be muddled unless these are solved. This section aims to clarify some of the historical issues.

First, Sudduth does not draw the right conclusion from the historical data. For not only does his historical survey actually show that it was only in the early twentieth century that a few neo-orthodox theologians 
objected to natural theology, but that their objections were based on the authority of Hume and Kant rather than distinctively reformed doctrine. ${ }^{20}$ Yet both the title and the overall argument of the book are formulated in terms of 'the reformed objection to natural theology'. Sudduth rightly defines 'reformed' in connection with the confessions codified by the synods of Dort and Westminster. ${ }^{21}$ However, since these documents endorse natural theology and the modern authors he argues against deviate from reformed orthodoxy on this issue, they simply do not represent a 'reformed objection to natural theology'. Sudduth appears to acknowledge this to some extent. For not only does he write that the Humean and Kantian assumptions of the neo-orthodox theologians make it 'exceedingly difficult to regard the objections in question as good project objections', but that 'their distance from the Reformed orthodoxy makes them poor candidates for distinctly Reformed objections. ${ }^{22}$ Indeed, such objections are incompatible with Christian theism in general and the Reformed tradition in particular. ${ }^{23}$ Yet, the book is framed by such opposition, especially among Abraham Kuyper's and Herman Bavinck's American followers. If these relatively unknown theologians had had sufficient philosophical training and had presented philosophical arguments, they may have merited philosophical analysis. However, their objections are, in Sudduth's own words, 'the least impressive. ${ }^{24}$ Humean and Kantian assumptions could of course be refuted by philosophical criticism and the progress of natural science, but Sudduth is brief here. ${ }^{25}$ These theologians appear merely to assume Hume's and Kant's authority for contextual reasons, while being badly informed of the philosophical rigour of their own tradition and the ancient tradition of natural theology. ${ }^{26}$ Their opposition seems rather to call for a different line of explanation. ${ }^{27}$ So, Sudduth should but did not conclude that the 'reformed objection to natural theology' is just a (philosophical) pseudo-issue. ${ }^{28}$

Second, Sudduth's historical argument does not deal with the right sources in the sixteenth and seventeenth centuries. If we want to know about natural theology in the reformed Church or in general before the nineteenth century, it is to philosophical works and not to theological works that we should turn. For traditionally natural theology is a philosophical discipline, where 'natural' is synonymous with 'physical.. ${ }^{29}$ At least since Aristotle the most foundational investigation of natural science concluded that (some) changing material things have immaterial causes: the First Cause and human intelligence. These arguments showed that the meaning of the term 'being' has to be extended to include both 'material 
being' and 'immaterial being', and thus establish a science beyond physics, namely metaphysics. Metaphysics is then theology, because no science is complete until the principle of its subject is known and God is the cause of being and the goal of metaphysics. ${ }^{30}$ This understanding of natural theology was from the beginning endorsed by members of good standing in the reformed Church. For instance, according to the influential Pietro Martire Vermigli, physics (or generic natural science) demonstrates that there are immaterial things and metaphysics therefore considers 'God and intelligence. ${ }^{31}$ In the words of Bartholomaeus Keckermann, 'thus our system of physics concludes that God is the author and sustainer of nature' and so metaphysics deals with God as 'the foundation and source of all substance. ${ }^{32}$ This is also the reason why Thomas Barlow's six metaphysical disputations concerning God are not so much devoted to his existence but to his attributes. ${ }^{33}$ In short, according to Alsted, 'natural theology is judged to be a part of philosophy. ${ }^{34}$ Examples could be multiplied, but I trust that these sources suffice to illustrate that it is to works in physics and metaphysics that we have to turn in order to know about natural theology in the reformed Church. ${ }^{35}$

However, Sudduth attempts to discover the nature of natural theology in the reformed Church from commentaries on Romans 1 and Psalm 19 and dogmatic treatises. ${ }^{36}$ Yet, he is aware that philosophical arguments are actually found elsewhere: 'These are often cast in a more rigorous form as logical demonstrations, resembling the argumentation of medieval scholasticism, and, for some arguments, ultimately the natural theology of Aristotle's Physics and Metaphysics. ${ }^{37}$ One reason for this mistaken identification appears to be his heavy dependence on the careful scholarship of John Platt and Richard Muller, which is theological in scope.$^{38}$ But the major reason seems to be the anachronistic interpretation of natural theology as a theological and not a philosophical discipline. It would seem that natural theology is not so conceived until the late eighteenth century. For then the name 'apologetics' is coined for a new discipline that is placed within the theological curriculum, ${ }^{39}$ and the background to this would seem to be the Enlightenment worry about the reasonableness of faith in God. ${ }^{40}$ Ironically this frames natural theology as the particular response to the Enlightenment that both the neo-orthodox theologians and Sudduth want to escape.

Third and last, Sudduth's inaccurate identification of sources and anachronistic view of natural theology unfortunately lead him into confusing the traditional and modern understandings of natural 
theology in general ${ }^{41}$ and the position of reformed orthodoxy with that of Descartes, Leibniz and Clarke in particular. ${ }^{42}$ At least since Aristotle natural theology was 'a system of theology [...] independent of dogmatic theology', but it plainly did not serve 'as its rational foundation. ${ }^{43}$ Aristotle did of course not acknowledge a divine revelation and those convinced of his conception of natural theology, such as Aquinas and philosophers within reformed orthodoxy, obviously did not suppose that it served as a rational foundation for revealed theology. Sometimes Sudduth concurs that the view of natural theology as the foundation of supernatural theology is found elsewhere. It 'came into prominence during the heyday of classical foundationalism, [and] typically construed theistic arguments as demonstrative arguments, especially where dogmatics came under the influence of Cartesian and Wolffian rationalism. ${ }^{44}$ Bypassing for now the issue of demonstration, it is nevertheless not clear where the subordination of supernatural theology to natural theology is to be located. Although (perhaps) implicit in Descartes ${ }^{45}$ and Wolff, ${ }^{46}$ the earliest instances may be Isaac Sigfrid and Daniel Wyttenbach; but they still fall short of Sudduth's 'pre-dogmatic model. ${ }^{47}$ Perhaps this rationalist account is just a straw man produced by early twentieth-century neoorthodox theologians.

So, in this section I have argued that in the reformed Church natural theology was traditionally viewed as the culmination of physics and the founding of metaphysics. It was a distinctively philosophical business for its own sake and not an apologetical enterprise for the sake of theology. I have argued that Sudduth inaccurately identifies the sources of natural theology in the reformed Church and fails to draw the conclusion that the neo-orthodox objection against a modern view of natural theology does not merit philosophical analysis. If philosophers are not to carry on the pseudo-issue of 'reformed epistemology', they need to give heed to the historical sources.

\section{NATURAL THEOLOGY IN THE REFORMED CHURCH REVISITED EPISTEMOLOGICALLY}

Another central issue in the discussion about natural theology in the reformed Church, is the thesis that faith in God can be reasonable without arguments. Sudduth develops an epistemological argument on that thesis in favour of a natural theology. ${ }^{48}$ The aim is to develop 'the dogmatic function' or 'the dogmatic model' of natural theology 'as part 
of the discourse of dogmatic theology', and to defend 'the normative status of this Reformed endorsement of natural theology. ${ }^{49}$ His 'primary goal' is to defend this within the reformed tradition and the 'second goal' is to 'clarify the nature of natural theology itself'. ${ }^{50}$ Although sixteenth and seventeenth century philosophers of good standing in the reformed Church (as well as the late medieval thinkers they followed, especially Aquinas) were not as explicit and comprehensive as contemporary philosophers, it is possible and desirable to develop a position analogically extended with theirs. However, Sudduth's epistemological conception of natural theology is problematic and this section will show that it confuses natural and supernatural theology, presumes knowledge as justified true belief, and prejudges demonstration.

First, Sudduth confuses rather than clarifies natural theology. He recognizes that 'the dogmatic model of natural theology' may be circular; namely that 'Scripture would supply the actual premises of theistic arguments. ${ }^{51} \mathrm{He}$ wants to 'avoid reducing natural theology to a series of biblical claims about natural revelation', ${ }^{52}$ and attempts to show that his 'model' does not abolish the philosophical nature of natural theology. This is done by distinguishing between three ways in which it 'can depend on Scripture'. The Bible can (1) provide 'a justification for engaging' in natural theology; ${ }^{53}$ (2) 'eliminate certain conclusions of natural theological reasoning'54 and (3) inform 'what the theistic evidence is, and perhaps also what truth about God is said to follow from the evidence' ${ }^{55}$ However, this attempt of preserving the distinction between philosophy and theology does not succeed. In the case of (1) it is not natural theology but simply revealed theology. For in this case 'Scripture testifies that there is evidence in the created order from which conclusions about the existence and nature of God may be inferred'. ${ }^{56}$ It seems strange that we need revelation in order to engage in philosophy. Surely philosophical arguments stand or fall on their own, just as theology stands on its own given revelation, and Christians can take the existence of God on faith in that revelation. But perhaps if some Christians get confused (such as Barth, Bavinck and their followers) and do not understand that establishing whether the proposition 'God exists' is true is desirable in and of itself, then they may be helped by a revelation saying that it can be established apart from revelation. Yet, such an argument would be based on revelation and thus not be philosophical but theological. In the case of (2) Scripture does supply the actual premises against a philosophical argument and thus that counter-argument is not 
philosophical. Besides, if the philosophical argument is sound and valid, no divine revelation can eliminate the conclusion; and if the argument is unsound and/or invalid, philosophy can itself eliminate the conclusion. In the case of (3) the evidence and the inference are accepted on the basis of revealed information. It is again 'a series of biblical claims about natural revelation' and this entire project is merely 'situated within the theological framework of the Christian faith'. ${ }^{57}$ So this dogmatic model does not clarify but confuse natural theology with dogmatic theology. ${ }^{58}$ The former section of this paper also shows that Sudduth does not develop and defend the traditional 'Reformed endorsement of natural theology.'

My second objection is that natural theology should not be developed within the tripartite analysis of knowledge as justified or warranted true belief. This is, according to Sudduth, a 'deeply entrenched view of knowledge in the western philosophical tradition' and the recent discussions of this 'framework' 'are directly relevant to the role of inference and natural theology $\beta .^{59}$ Here it cannot be argued that that analysis is erroneous, but that it should not be presumed for natural theology. First, analysing knowledge as justified true belief appears to be the most recent empiricist attempt to overcome modern scepticism pasted onto Plato's Theaetetus. Not only is it of no more than a mid-twentieth-century origin, ${ }^{60}$ but its interpretation of Theaetetus is mistaken, ${ }^{61}$ and Gettier cases, generality problems, as well as the impasse between first person internalism and third person externalism (pertaining to ambiguities about 'ground,' 'adequacy' and 'the basing relation') make it highly dubitable and a likely cul-de-sac. ${ }^{62}$ Second, this analysis misconstrues our concept of knowledge ${ }^{63}$ For 'knowing' is used in diverse contexts with systematically diverse sensory, intellectual, actual, dispositional, intuitive, discursive, everyday, scientific, theoretical and practical meanings. In the context of the senses individual and concrete characteristics of things are known from neural signs, whereas in the context of the understanding universal and abstract characteristics are known from conventional signs, and so on. Thus owing to this ambiguity 'knowledge' cannot be defined in terms of necessary and sufficient conditions, but its usage in different contexts with systematically different meanings can only be described. ${ }^{64}$ Likewise the notion of justification is erroneously assumed to be univocal, since only in some cases is justification appropriate, but even then it will vary in between those cases. It is inappropriate to ask for a justification of how I know my name, but it is occasionally appropriate to ask for the justification of the conjugation of the Latin verb 'docere' and the 
extension of the term 'aluminium', although these justifications will be very different. Moreover, knowing does not entail believing or supposing or opining. For this entailment is commonly argued from cases where something was known but is not so any longer. For instance, I knew I put my shoes under the shelf, but then unbeknownst to me my wife moved them into the cellar. Under those circumstances I take, suppose or believe my shoes to be under the shelf, but I do not know it. Yet, the negative case of not-knowing but believing cannot be turned into the positive case of knowing therefore believing. For 'knowing therefore believing' does not follow from 'not-knowing but believing. Besides, in many situations the 'difference between knowing and believing is that between being and not being fully confident; and the entailment view would mean, absurdly, that not being fully confident is compatible with being fully confident (that if a person is not fully confident he may be fully confident). ${ }^{65}$ Lastly, the framework inherited from modern scepticism is needless, since the meaning of the words by which doubt is expressed cannot be doubted, some propositions are known by virtue of themselves, and the senses are self-correcting. ${ }^{66}$

Third, rejecting traditional realist and adopting modern sceptical epistemology, ${ }^{67}$ the alternative natural theology Sudduth favours is Richard Swinburne's probabilistic argument from simplicity. ${ }^{68}$ However, for all its admirable argumentative rigour, 'God' as a simpler explanation may be the best explanation only when there is no other evidence - such as a demonstrative syllogism (more on this in a moment). Nor does simplicity guarantee truth. For a complex explanation may be closer to the truth than a simple one, and an as yet unknown hypothesis may explain better than any of the known ones. ${ }^{69}$ Even so, Swinburne's theology is an unlikely partner in Sudduth's project of defending and developing natural theology within the reformed tradition. For in contradiction to confessional reformed theology, Swinburne apparently defends anthropomorphism (univocity), tritheism, Pelagianism and Socinianism. ${ }^{70}$

Last, Sudduth's replacement of the traditional natural theology in the reformed Church in favour of 'an inductive, cumulative case for theism' is cursory. ${ }^{71}$ Consider this argumentative sketch:

Whatever is moved is moved by another.

There cannot be an endless series of moved movers.

There must be an unmoved mover. ${ }^{72}$ 
Much can be said about these deceptively simple sentences, but I will use them only to suggest that it is premature to 'turn away from Aristotelianbased arguments. ${ }^{73}$

It is often heard, and Sudduth claims, that a demonstrative syllogism assumes that God is 'proven in a rationally compelling manner from various self-evident or epistemically certain truths. ${ }^{74}$ However, considerable difficulties face anyone who wishes to argue the existence of God philosophically and it would be silly to suppose that the mere statement of these three sentences will change anyone's mind or even life. Language is a social thing where the speaker has to use words of significance for the listener in order to convince him or her. These premises are not supposed to be self-evidently true in the sense of 'the denials of which are intrinsically absurd or contradictory. ${ }^{75}$ Rather it is supposed that these sentences only have significance for and can be judged true by a listener who has gone through the investigation into the fundamental concept of nature, namely change, and asks about the ultimate explanation of all change: what is it that gets gravity, electromagnetism, and weak and strong radioactivity going? So, the syllogism is a very condensed, if not truncated, expression of a vast analysis of our primary physical notions. ${ }^{76}$

Nor is it true that the premises are assumed to have strong epistemic credentials' in the sense that they are pretended to be indubitable, infallible or incorrigible by 'all rational cognizers. ${ }^{77}$ Rather they purport to depend on the difficult efforts of sensory experience in natural science. They are the outcome of abstractive (as opposed to enumerative) induction, namely what is (or can be) sensed is taken up in language by distinguishing the universal and abstract from the individual and concrete. Humans perform such a fundamental operation every day (e.g. 'All dogs bark'), and the premises above assume the inductive investigations terminating in the first principle about change. Unless we have this intellectual power to form universal expressions from sense experience, we could not explain why universals apply to individuals. ${ }^{78}$

Sudduth does not follow Hume in denying the first premise, ${ }^{79}$ but some clarification of it is needed to avoid misunderstanding. The premise follows from the examination culminating in the definition of change as the actualisation of what is potentially $F$ insofar as it is potentially $F$, and the demonstration of the subject of change as potentiality. This premise is stated in terms of the most well-known kind of change, namely change in location or change through space. We constantly sense something 
moving and a denial of this would itself involve a move. The syllogism does not deny that a (typical) dog cannot wag its tail or leap, since in such self-motion one part is moving another. In it, as in everyday English, the verb 'move' (with its derivative 'mover') is used both transitively and intransitively. The legs of the dog are moved by its central nervous system, and when the central nervous system transitively moves the legs, that system is intransitively moving. In this way it is claimed that things in motion are caused to be in motion by another. Yet, the first premise is not merely an application of a principle of causality but one of modality. The process of change is the actualisation of what is potential insofar as it is potential. The process of change in the dog is the realisation of its capacity for leaping insofar as it has capacity for leaping. But potentiality cannot actualise itself. So, in order for change to take place, there has to be something actual that can cause something potentially $F$ to be actually $F$.

It seems that Sudduth would not deny the second premise, but it may also be misinterpreted. It depends on investigations into actual and potential infinity, continuous and discrete quantity, and mathematical and physical division. A 'moved mover' is something that moves both intransitively and transitively. The premise contends that the series of what is moving both intransitively and transitively cannot be infinite. For moving intransitively and transitively are simultaneous. In leaping the legs of the dog and the central nervous system move at the same time, and the central nervous system and ions move at the same time, and so on. But every potential motion is initiated by something actual, since only something actual can cause something potentially $F$ to be actually $F$. If whatever is intransitively moved also is transitively moved, then there is always something potential in the cause(s) of whatever is intransitively moved. So the second premise does not claim that no series of movers cannot stretch back infinitely in time, but that it cannot be infinite at one and the same time. There is no regression into an actual infinity in the series of causes operating here and now.

The argument concludes then that there must be an unmoved mover, namely something that ultimately actualises every potential motion here and now. An unmoved mover is what begins the motion of what is in motion without being in motion itself. It is something that moves transitively but not intransitively. It may be objected that this conclusion is very far from what is usually predicated 'God', but this misconstrues the argument. For this is not a why-demonstration but a that-demonstration; ${ }^{80}$ it does not demonstrate what something is 
but that something is. Motion is not the cause of the unmoved mover but the cause of our knowledge of the unmoved mover. It is granted that much further argumentation is needed, and this is what physics and metaphysics traditionally undertake. Physics proceeds and culminates with the conclusion that the unmoved mover is immaterial and thereby establishes a discipline beyond physics, namely metaphysics. ${ }^{81}$ This latter discipline undertakes to further investigate the cause and end of being by the laborious attempt to develop a language with which to speak about God. ${ }^{82}$ Then metaphysics is called 'theology'. Still, arrival at anything like the Christian doctrine of God is (arguably) impossible by philosophical argumentation. ${ }^{83}$ This will only be disappointing on the assumption that there are or must be facile arguments for God.

\section{CONCLUSION}

In this paper I have refuted the recent and erroneous opinion that there was a peculiar epistemology in the reformed Church which made it negative to natural theology. Regrettably I have also found Michael Sudduth's assessment of this issue faulty. First I argued that there was an early and unanimous adoption of natural theology as the culmination of physics and the foundation of metaphysics by sixteenth and seventeenth century philosophers of good standing in the reformed Church. Second I argued that natural theology cannot be based on revelation, should not assume a peculiar analysis of knowledge and must not pass over demonstrative natural theology.

I began this paper by conceding that its title was confused. However, perhaps the title may also suggest that the paper concerns a natural theology that has been subjected to reform; maybe freed of errors or abuses, and then restored to its previous form. Perhaps after all there is, can or should be a 'reformed' natural theology after modernity, namely a natural theology that is formed on the intelligibility of our most general physical concepts and explored in the abstruseness of our metaphysical notions. But that is matter for another occasion. ${ }^{84}$ 
1. For instance, "the Reformed tradition has taken a dim view of natural theology, and any sort of evidentialist apologetics." John Greco, 'Reformed Epistemology', The Routledge Companion to Philosophy of Religion, eds. Chad Meister and Paul Copan (London: Routledge, 2007), p. 630.

2. Alfred J. Freddoso, 'Ockham on Faith and Reason', Cambridge Companion to Ockham, ed. Paul Vincent Spade (Cambridge: Cambridge University Press, 1999), p. 330. Somewhat earlier Freddoso writes about the traditional view: 'as long as human reason is cut off from the illumination made available through the salvific action of Jesus Christ, it cannot perceive fully or definitely the metaphysical and moral truths that constitute the object of the classical for philosophical wisdom.' (p. 328)

3. Alvin Plantinga, 'The Reformed Objection to Natural Theology', Proceedings of the American Catholic Philosophical Association 54 (1980), p. 49; Alvin Plantinga, 'Reason and Belief in God', Faith and Rationality: Reason and Belief in God, eds. Alvin Plantinga and Nicholas Wolterstorff (Notre Dame: University of Notre Dame Press, 1983), p. 63.

4. For reasons of space references will here be limited to a minimum. But, for example, Plantinga bypasses the ecclesiastical standards of the Belgic Confession (1561) art. II (for instance, in J.N. Bakhuizen van den Brink, De Nederlandse Belijdenisgeschriften in Authentieke Teksten met Inleiding en Tekstvergelijkingen, 2 ed. (Amsterdam: Ton Bolland, 1976).) and the Westminster Confession (1646) ch. I.i. and Larger Catechism (1648) q. 2 (for instance, in S.W. Carruthers, ed., The Westminster Confession of Faith: The Preparation and Printing of its Seven Leading Editions and a Critical Text (Manchester: R. Aikman \& Son, 1937), and in John R. Bower, ed., The Larger Catechism: A Critical Text and Introduction (Grand Rapids, Michigan: Reformation Heritage Books, 2010). Similarly he sidesteps standard works such as Philipp Melanchthon, Initia doctrinae physicae, Philippi Melanchthonis opera quae supersunt omnia, ed. Karl Gottlieb Bretschneider (Halle: Schwetschke, 1846, 1549), pp. 200-06, Bartholomaeus Keckermann, Praecognitorum philosophicorum libri duo: naturam philosophiae explicantes et rationem eius tum docendae tum discendae monstrantes (Hanover: Guilhelmus Antonius, 1612), pp. 86-124 with the appendix "Brevis et simplex consideratio controversiae hoc tempore à nonullis motae de pugna philosophiae \& theologiae" pp. 81-200, Johann Heinrich Alsted, Theologia naturalis: exhibens augustissimam naturce scholam in quâ creaturce Dei communi sermone ad omnes pariter docendos vtuntur ([Frankfurt am Main?]: Antonius Hummius, 1615), Thomas Barlow, Exercitationes aliquot metaphysicae de Deo, 2 ed. (Oxford: Lichfield, 1658), Thomas Halyburton, Natural Religion Insufficient and Revealed Necessary to Man's Happiness in his Present State: A Rational Enquiry into the Principles of the Modern Deists (Edinburgh: Andrew Anderson, 1714), and Thomas Chalmers, On Natural Theology, The Works of Thomas Chalmers, vol. 1-2 (Glasgow: William Collins, 1835). One could add the very early Lambert Daneau, Physice Christiana, siue, Christiana de rerum creatarum origine et $v s u$, disputatio, 2 ed. (Geneuæ: Petrus Santandreanus, 1579). I hesitate because of its mix of theology and philosophy, but it testifies to an optimistic view of philosophy. In the development of my argument below reference will be made to further philosophical sources.

5. Plantinga, 'The Reformed Objection to Natural Theology', pp. 49-53, 57-58, and Plantinga, 'Reason and Belief in God', pp. 64-73.

6. For example, John Beversluis, 'Reforming the "Reformed" Objection to Natural Theology', Faith and Philosophy 12 (1995), Hunter Brown, 'Alvin Plantinga and Natural Theology', International Journal for Philosophy of Religion 91 (1991), Donald Hatcher, 
'Plantinga and Reformed Epistemology: A Critique', Philosophy and Theology 86 (1986), Paul Helm, 'John Calvin, the sensus divinitatis, and the noetic effects of sin', International Journal for Philosophy of Religion 43 (1998), Paul Helm, Faith with Reason (Oxford: Oxford University Press, 2000), pp. 84-87, Paul Helm, John Calvin's Ideas (Oxford: Oxford University Press, 2004), pp. 265-76, Derek S. Jeffreys, 'How Reformed is Reformed Epistemology? Alvin Plantinga and Calvin's 'Sensus Divinitatis”, Religious Studies 33 (1997), Norman Kretzmann, 'Evidence against Anti-Evidentialism', Our Knowledge of God: Essays on Natural and Philosophical Theology, ed. K. J. Clark (Dordrecht: Kluwer Academic Press, 1992), Stephen Maitzen, 'God and Other Theoretical Entities', Topoi 14 (1995), Duncan Pritchard, 'Reforming Reformed Epistemology', International Philosophical Quarterly 43 (2003), Thomas A. Russman, 'Reformed Epistemology', Thomistic Papers IV, ed. Leonard A. Kennedy (Houston, TX: Center for Thomistic Studies, 1988), Stephen J. Wykstra, 'On Behalf of the Evidentialist - A Response to Wolterstorff', Philosophy of Religion in the 21st Century, eds. D. Z. Phillips and Timothy Tessin (Gordonsville, VA: Palgrave Macmillan, 2001). I evaluated other metaphysical and epistemological arguments of Plantinga in Sebastian Rehnman, Tänkesätt: Studier i Alvin Plantingas filosofi (Skellefteå: Norma, 2004).

7. Alvin Plantinga, 'Reformed Epistemology', A Companion to Philosophy of Religion, eds. Charles Taliaferro, Paul Draper and Philip L. Quinn, 2 ed. (Malden, Mass.: WileyBlackwell, 2010), p. 674; Nicholas Wolterstorff, 'The Reformed Tradition', A Companion to Philosophy of Religion, eds. Charles Taliaferro, Paul Draper and Philip L. Quinn, 2 ed. (Malden, Mass.: Wiley-Blackwell, 2010). In the Stanford Encyclopedia of Philosophy see, for example, Peter Forrest “The Epistemology of Religion”, sect. 7-8, Charles Talliaferro "Philosophy of Religion" 4.2, John Bishop "Faith" and Richard Amesbury "Fideism". In the Routledge Encyclopedia of Philosophy see, for example, Scott MacDonald "Natural Theology" sect. 2, and William Alston "History of Philosophy of Religion", sects. 1 and 8. Already in 1997 Jeffreys pointed out that 'many simply rehearse his [Plantinga's] discussion of Calvin superficially'. Jeffreys, 'How Reformed is Reformed Epistemology? Alvin Plantinga and Calvin's 'Sensus Divinitatis”, p. 419. For a more accurate overview of this tradition, see Daniel von Wachter, 'Protestant Theology', The Routledge Companion to Philosophy of Religion, eds. Chad Meister and Paul Copan (London: Routledge, 2007).

8. Michael Sudduth, The Reformed Objection to Natural Theology (Farnham: Ashgate, 2009).

9. Ibid., cp. pp. 46-47, 49, 53, 101, 50, 77, 225.

10. Ibid., pp. 170-1, 203-09, 26.

11. Ibid., p. 45.

12. Ibid., p. 49.

13. Ibid., p. 4, cp. p. 51.

14. Ibid., pp. 4-5, 52-53.

15. Ibid., p. 223.

16. Ibid., p. 6.

17. Ibid., p. 223.

18. In this paper I use the terms 'neo-orthodox' and 'neo-orthodoxy' inclusive of both Abraham Kuyper and Karl Barth together with their followers. The Concise Oxford Dictionary of World Religions (ed. John Bowker (Oxford: Oxford University Press, 2000)) describes the use of 'neo-orthodoxy' in the following way: 'A Protestant Christian reaction against 19th-cent. liberalism in theology. The reaction was not organized, and is particularly associated with K. Barth. Quintessentially, Neo-Orthodoxy rejected the 
liberal belief that it is possible to argue from experience to God, or, more extremely, that theology is disguised anthropology' Although Kuyperianism and Barthianism differ on other issues, they agree in their rejection of arguments to God and are thus in this paper both referred to as 'neo-orthodox'. Cp. also 'repristination theology' in Bengt Hägglund, History of theology, 3 ed. (St. Louis: Concordia, 1968), pp. 363-65.

19. Unless otherwise indicated, all translations in this paper are my own. Abbreviated quotations are indicated in two ways. When a citation is abbreviated within one and the same paragraph, this is indicated by '[...]'. When a citation is abbreviated over two or more paragraphs, this is indicated by '[---]'.

In this paper I also leave out a distinction that Sudduth emphasises. He distinguishes between 'natural theology $\alpha$ ' and 'natural theology $\beta$ ', namely between 'natural theology as natural knowledge of God and natural theology as rational proofs or arguments' (Sudduth, The Reformed Objection to Natural Theology, p. 4). However, since it is mainly the second half of the distinction that is discussed in his book (apart from 'the immediacy claim') and this more narrow identification of natural theology has dominated the western philosophical tradition (as Sudduth concedes; cp. pp. 1 and 222), it suffices to use only the argumentative sense here.

20. There is, since Hume's lifetime, a tradition within the reformed Church of arguing against him. For instance, George Campbell, A Dissertation on Miracles: Containing an Examination of the Principles Advanced by David Hume (Edinburgh: Kincaid \& Bell, 1762), and Thomas Chalmers, On the Miraculous and Internal Evidences of the Christian Revelation, The Works of Thomas Chalmers, vol. 3 (Glasgow: William Collins, 1842), pp. 70-146. This majority view contrasts sharply with that of neo-orthodoxy.

21. Sudduth, The Reformed Objection to Natural Theology, p. 2.

22. Ibid., p. 224, similarly p. 26.

23. Ibid., p. 205.

24. Ibid., p. 225.

25. Ibid., pp. 203-09. There is a historical irony in that the prominent philosophers Plantinga and Wolterstorff endorse Kuyper's and Bavinck's Kantian opposition to natural theology, while they themselves reject Kantianism: Alvin Plantinga, Warranted Christian Belief(Oxford/New York: Oxford University Press, 2000), pp. 9-30; Nicholas Wolterstorff, 'Is it Possible and Desirable for Theologians to Recover from Kant?', Modern Theology 14 (1998).

26. On the twentieth century protestant misunderstanding of the tradition, see the sadly neglected Arvin Vos, Aquinas, Calvin, and Contemporary Protestant Thought: A Critique of Protestant Views on the Thought of Thomas Aquinas (Grand Rapids, Mich.: Eerdmans, 1985).

27. There may be a sociological line of explanation. Cp. George M. Marsden, Understanding Fundamentalism and Evangelicalism (Grand Rapids, Mich.: W.B. Eerdmans, 1991), and James D. Bratt, Dutch Calvinism in Modern America: A History of a Conservative Subculture (Grand Rapids: Eerdmans, 1984). But Paul Helm reminded me that there may be a deeper theological explanation. The neo-orthodox has a different doctrine of sin so that they deny the orthodox affirmation of natural theology and natural law. Cp. Abraham Kuyper, Encyclopedia of Sacred Theology: Its Principles, trans. J. Hendrik De Vries (New York: Charles Scribner's Sons, 1898), and Karl Barth, Nein! Antwort an Emil Brunner, Theologische Existenz heute (München: C. Kaiser, 1934). 
28. Once Sudduth himself writes 'there is consensus in the Reformed tradition on the propriety of the project of developing theistic arguments' (Sudduth, The Reformed Objection to Natural Theology p. 4). Thus there is no analysandum. Moreover, there is (at least historically) no basis for his distinction between 'model-specific objections' and 'project objections' to natural theology (ibid. pp. 6, 54). For the issue is really only about objections to specific uses of natural theology and such objections are found in many traditions in and out of the Church (whether reformed or not).

Perhaps one may hope that 'Kuyperian epistemology' gains acceptance instead of 'reformed epistemology', since there appears to be no claim to a distinctive theory of knowledge in the reformed Church until Abraham Kuyper. See especially Abraham Kuyper, Lectures on Calvinism (Grand Rapids: Eerdmans, 1931, 1898), and Kuyper, Encyclopedia of Sacred Theology: Its Principles. Cp. 'Our most influential college teachers were all "Kuyperians". Nicholas Wolterstorff, 'Reformed Epistemology', Philosophy of Religion in the 21st Century, eds. D. Z. Phillips and Timothy Tessin (Gordonsville, VA: Palgrave Macmillan, 2001), p. 41.

29. The name comes from Augustine who took it from Marcus Terentius Varro who seems to reflect a still earlier usage: 'there are three kinds of theology [...] the second physical, [...] may be called natural [... and] is that which philosophers use'. Augustine, De civitate Dei, Corpus christianorum, Series latina, vol. 47-48 (Turnholt: Brepols, 1954-, 413-422) VI.v cp. VIII.i, and Marcus Tullius Cicero, De natura deorum: liber I, Cambridge Greek and Latin classics, ed. Andrew R. Dyck (Cambridge: Cambridge University Press, 2003, 45), ch. i-ii. The term may have been introduced by a Greek Stoic philosopher according to C. C. J. Webb, Studies in the history of natural theology (Oxford: Clarendon, 1915), p. 69, and Werner Jaeger, The Theology of the Early Greek Philosophers: The Gifford Lectures 1936, trans. Edward S. Robinson (Oxford: Clarendon Press, 1947), pp. 3-4.

30. For instance, Aristotle, Physics: A Revised Text with Introduction and Commentary, Oxford Classical Text, ed. W. D. Ross (Oxford: Clarendon Press, 1936) VII-VIII, Aristotle, De anima: Edited with Introduction and Commentary, Oxford Classical Text, ed. W. D. Ross (Oxford: Clarendon Press, 1961), III, Aristotle, Metaphysics: A Revised Text, with Introduction and Commentary, Oxford Classical Text, ed. W. D. Ross, 2 vols. (Oxford: Clarendon Press, 1924), 998b22-27, 1003a33-03b16, 28a29-30, 26a27-32, 64b1-14, and generally XII. 'Aristotle's identification of first philosophy with natural theology is continuous with the approach of his predecessors in the specific and crucial respect that the proof for the existence of God is the conclusion of reasoning within the science of nature. His further hypothesis that natural theology is identical with the science of being, distinct from the science of nature, bears the stamp of Parmenidean dissent from the Milesian tradition.' L.P. Gerson, God and Greek Philosophy: Studies in the Early History of Natural Theology (London: Routledge, 1990), p. 82, cp. p. 96.

31. Pietro Martire Vermigli, In primum, secundum et initium tertii libri Ethicorum Aristotelis ad Nicomachum commentarius, ed. Guilio Santeranziano (Zürich: Froschauer, 1563), p. 3, cp. pp. 163, 224, 26, and Pietro Martire Vermigli, Loci communes (London: John Kyngston, 1576), p. 31. He may have acquired this view while studying under the Thomistic chair of metaphysics at the University of Padua. Cp. Thomas Aquinas, Sententia libri Metaphysicae, eds. Roberto Busa and Enrique Alarcón, 2 ed. (Taurini: Marietti, 1950, 1270-3) prooemium, lib. 3 1. 6 n. 6 (398), 6.1.27 (1170), 11.7.21 (2267), Thomas Aquinas, In Aristotelis libros De sensu et sensato commentarium, ed. Raimondo Spiazzi, 3 ed. (Taurini: Marietti, 1949, 1268-1270), p. 1.1 n. 1 and 4, Thomas Aquinas, Super Boëthium 
De Trinitate, Opera omnia, vol. 50 (Rome/Paris: Commissio Leonina/Éditions Du Cerf, 1992, 1257-8), Pars 3 q. 5 a. 3 co. 5, and Aristotle, Physics: A Revised Text with Introduction and Commentary 194b15. Vermigli does not think that metaphysics can attain an account of the nature of God: Vermigli, In primum, secundum et initium tertii libri Ethicorum Aristotelis ad Nicomachum commentarius, p. 82. For God as God is not an object of metaphysics, but only as the cause of being, since God is beyond the categories of being: $\mathrm{cp}$. Ibid. pp. 224, 158, 156 and 137. Analogical predication about God is therefore treated here and there in this work; for example, pp. 142, 151-152, 156, 268-269. For an argument of the usefulness of physics in general and for the knowledge of God in particular, see Girolamo Zanchi, 'Prolegómena', Aristotelous phusikēs akroaseōs è peri archōn, ed. Girolamo Zanchi (Strassburg: Vuendelinus Rihelius, 1553). For the general assumption by a philosopher in the reformed Church that metaphysics deals with God as the ultimate principle of everything and especially of created or separate minds, see for instance Rudolphus Goclenius, Isagoge in peripateticorum et scholasticorum primam philosophiam, quae dici consuevit metaphysica (Frankfurt: Zacharias Palthenius, 1598), praefatio.

32. Bartholomaeus Keckermann, Systema physicum, 3 ed. (Hanover: Ioannes Stockelius, 1623), p. 828, and Bartholomaeus Keckermann, Scientiae metaphysicae compendiosum systema, Opera omnia quae extant, vol. 1 (Geneva: 1614, 1609), p. 2015 respectively. Cp. Philipp Melanchthon, 'De physica', Philippi Melanchthonis opera quae supersunt omnia, ed. Karl Gottlieb Bretschneider, Corpus reformatorum (Halle: Schwetschke, 1843, 1542), XI.558r, Philipp Melanchthon, Erotemata dialectices, Philippi Melanchthonis opera quae supersunt omnia, ed. Karl Gottlieb Bretschneider (Halle: Schwetschke, 1846, 1547), p. 682, Clemens Timpler, Physice seu philosophice naturalis systema methodicum (Hanover: Guilielm Antonius, 1605), Epistola dedicatoria 5-6 (my pagination), cap. I q. 5 pp. 14-15, cap. II. q 5-9 pp. 27-36, cap. XII q. 5 p. 171, Franco Burgersdijk, Idea philosophiae naturalis: sive methodus definitorum \& controversiarum physicarum (Oxford: Henry Curteyne, 1641, 1631), pp. 27-30, Gilbertus Jacchaeus, Institutiones physicae (Schleusingae: Peter Schmid, 1635), pp. 71-73, and Johannes Maccovius, Metaphysica theoretico-practica, Opuscula philosophica omnia, ed. Nicolai Arnold (Amsterdam: Elzevir, 1660), pp. 4, 12-14. Compare also the physical basis of natural theology and the responses to the objection that 'natural theology is nothing else than metaphysics' in Alsted, Theologia naturalis: exhibens augustissimam nature scholam in quâ creaturce Dei communi sermone ad omnes pariter docendos vtuntur, praefatio pp. 12-13 and pt I p. 8 respectively. For one succinct formulation of the physical argument that God is, see for instance Rudolphus Goclenius, Scholae seu disuputationes physicae (Marburg: Paul Egenolph, 1591), pp. 159-60.

33. Barlow, Exercitationes aliquot metaphysicae de Deo.

34. Alsted, Theologia naturalis: exhibens augustissimam naturce scholam in quâcreaturce Dei communi sermone ad omnes pariter docendos vtuntur, praefatio 13.

35. The priority of physica for natural theology in reformed orthodoxy can also be seen in the contention that demonstrations for the existence of God can only be from effects to cause (a posteriori) and not from cause to effect (a priori). For example, Barlow, Exercitationes aliquot metaphysicae de Deo, pp. 128-30, 37, 66-67, Johann Heinrich Alsted, Metaphysica, tribus libris tractata (Herborn: 1616), p. 87, and Johannes Maccovius, Distinctiones et regulae theologicae ac philosophicae, ed. Nicolai Arnold (Oxford: Roberti Blagrave, 1656, 1653), p. 169. The first thing humans understand is that they sense reality or something real. For 'there is nothing in the intellect that was not before in the senses'. 
(Burgersdijk, Idea philosophiae naturalis: sive methodus definitorum \& controversiarum physicarum, p. 94.) So, the proper object of human intelligence is what material things are, and they are therefore the kind of being that is the principal human analogate through which other kinds of being may be causally known. Thus the subject of metaphysics can only be described by reasoning from material effects to immaterial causes. This view is, by the way, another instance of Plantinga's discontinuity with the reformed tradition: Alvin Plantinga, The Nature of Necessity (Oxford: Clarendon Press, 1974), pp. 197-221.

This may also be the place to comment on Sudduth's material on intuition. Chapters 3-5 are all devoted to 'immediate knowledge of God'. Sudduth struggles to clarify what cognitio Dei insita signifies in sixteenth and seventeenth century reformed thought, but ends in claiming both that 'it is not inferential' and that it 'is spontaneously inferred' (p. 70; cp. pp. 97-99). Part of the problem seems to be that he conflates the traditional account that knowledge always begins from non-inferential sensory experience, with the modern view that there is knowledge independent of and logically prior to the senses. ('There is an important continuity, then, between [intuition in] the above nineteenthcentury Calvinistic theologians and [cognitio insita in] the Reformed scholastics.' (p. 74)) Thus he can claim that 'intuition yields a priori beliefs' (p. 129), which obviously is incompatible with traditional epistemology. There occur, though, more correct formulations (pp. 4, 57). Henceforth I bypass this issue.

36. In the philosophical genre, Sudduth only refers twice to Alsted's Theologia naturalis, but seems not acquainted with this primary text but rather dependent on secondary literature.

37. Sudduth, The Reformed Objection to Natural Theology, p. 48, cp. p. 67.

38. John Platt, Reformed Thought and Scholasticism: The Arguments for the Existence of God in Dutch theology, 1575-1650 (Leiden: Brill, 1982), and Richard A. Muller, PostReformation Reformed Dogmatics: The Rise and Development of Reformed Orthodoxy, ca. 1520 to ca. 1725, 4 vols. (Grand Rapids: Baker Academic, 2003), especially vols. 1 and 3. There are many references to sixteenth and seventeenth sources in Sudduth's first and third chapter, but they seem to be taken from Platt and Muller. He produces more original material on the nineteenth century.

39. Apologetics appears first to have been placed in the theological curriculum by Gottlieb Jakob Planck, Einleitung in die theologische Wissenschaften, 2 vols. (Leipzig: Crusius, 1794), I.xiv, 27-363, II.93-489, and Friedrich Schleiermacher, Kurze Darstellung des theologischen Studiums (Berlin: Realschulbuchhandlung, 1811), pp. 14-19, 92. (For these names I am indebted to B.B. Warfield, 'Apologetics', The Works of Benjamin B. Warfield, eds. Ethelbert D. Warfield, William Park Armstrong and Caspar Wistar Hodge, vol. 9 (New York: Oxford University Press, 1932, 1908), p. 3 (although Plank's and Schleiermacher's works do not appear in the bibliography). Warfield's article was originally published in The New Schaff-Herzog Encyclopedia of Religious Knowledge, I.232-238.) Planck and Schleiermacher are concerned with the divine origin of the Christian religion and the Church, but not explicitly with arguments for God's existence. The invention of the theological discipline of apologetics does not however deny the obvious, namely that Christians have since antiquity defended their faith and that many works in reformed dogmatics contain arguments for the existence of God.

Here it may be worth digressing on arguments that God exists in works of seventeenth century reformed dogmatics. First, these are normally not demonstrative syllogisms but rhetorical syllogisms or enthymeme. For instance, Françesco Turrettini, 
Institutio theologicae elencticae (Geneva: Samuel de Tournes, 1679-85), I.iii.7-8, III.i.5-21. Thus they are known to be incomplete (cp. Franco Burgersdijk, Institutionum logicarum, libri duo (London: Roger Daniels, 1651, 1637), p. 193). Second, the full title of such academic works often reveals a polemical aim, where 'elencticae' in Turrettini's title comes from the Greek elegkhos, 'examination' or 'refutation'. These arguments serve 'only an interest in systematic completeness. [---] Their discussions of the proofs recognise fully that believers fundamentally and ultimately need no proof precisely because they are believers - but also that believers do need, mediately, as it were, tools and weapons for the spiritual arsenals. The proofs fill a need in a world where doubts arise and atheists abound.' Muller, Post-Reformation Reformed Dogmatics: The Rise and Development of Reformed Orthodoxy, ca. 1520 to ca. 1725, III.170, cp. p. 79. Third, the place of such arguments can be explained in terms of the educational system. The original audience of such works already had a thorough training in philosophy and particularly in arguments about God both in physics and metaphysics before they entered the study of theology. Cp. Joseph S. Freedman, 'Philosophy Instruction within the Intitutional Framework of Central European Schools and Universities during the Reformation Era', History of Universities 5 (1985), Joseph S. Freedman, 'Classifications of Philosophy, the Sciences, and the Arts in Sixteenth- and Seventeenth-Century Europe', Modern Schoolman 72 (1994). Such arguments thus simply rehearse that the statement 'God exists' is intelligible outside the context of revelation. These works likely also points to the (future) homiletical context of their readers by the use of rhetorical syllogisms.

40. Several historical studies have in different ways established that it was only during the so-called Enlightenment that natural theology began to be used primarily in order to justify individual acts of faith. For instance, Guy de Broglie, 'La vraie notion thomiste des praeambula fidei', Gregorianum 34 (1953), Nicholas Wolterstorff, 'The Migration of Theistic Arguments: From Natural Theology to Evidentialist Apologetics', Rationality, Religious Belief, and Moral Commitment, eds. Robert Audi and William J. Wainwright (Ithaca/London: Cornell University Press, 1986), Nicholas Wolterstorff, John Locke and the Ethics of Belief (Cambridge: Cambridge University Press, 1996), pp. 118-33, John Clayton, Religions, Reasons and Gods: Essays in Cross-Cultural Philosophy of Religion, eds. Anne M. Blackburn and Thomas D. Carroll (Cambridge: Cambridge University Press, 2006) pp. 184-309. For a brief development and defence of the traditional (as opposed to the Enlightenment) conception of natural theology, see Sebastian Rehnman, 'Natural Theology and Epistemic Justification', Heythrop Journal 48 (2010).

41. Sudduth, The Reformed Objection to Natural Theology, cp. pp. 150-52, probably following early twentieth century reformed theologians.

42. Ibid., p. 172.

43. Ibid., p. 53. By this phrase Sudduth appears to mean that 'reason plays a substantive and formative role in the dogmatic system, including the subtle implication that faith, or at least the reasonableness of faith, rests on the prior establishment by reason of Christian doctrine'. (p. 53; cp. p. 101) 'It is an autonomous system based solely on the resources on human reason and constituting a justificatory preface to the system of revealed theology'. (p. 150) The Aristotelian position does of course not entail that; nor has that tradition claimed demonstrative syllogisms 'under the influence of modern foundationalism'. Ibid. p. 172.

$$
\text { 44. Ibid., p. } 177 .
$$


45. In his 'Dedication' Descartes writes that one ought to begin with demonstrations of the existence of God and the immortality of the soul by philosophical rather than theological arguments, and then in the meditations he attempts to prove these from his ideas about God and consciousness: René Descartes, Meditationes de prima philosophia, Euvres de Descartes, eds. Charles Adam and Paul Tannery, vol. 7 (Paris: Vrin, 1996, 1640). 46. Cp. Christian von Wolff, Theologia naturalis, methodo scientifica pertractata. Pars Prior, integrum Systema complectens, qua existentia et attributa Dei a posteriori demonstrantur (Frankfurt: Officina libraria Rengeriana, 1736), \$9. The position is not clear however.

47. Isaac Sigfrid and Daniel Wyttenbach, Theses theologice proecipua Christianoe doctrince capita continentes (Frankfurt: Hort, 1749), cp. i-iii with xiii-xvi. These disputations were held in 1747. In consideration of Sudduth's commendation of the work of Richard Swinburne (as will be seen below), it may be worth noting here the similarity between the accounts of Sigfrid/Wyttenbach and Richard Swinburne, Revelation: From Metaphor to Analogy, 2 ed. (Oxford: Clarendon Press, 2007), pp. v-vi, 79-85.

48. Sudduth, The Reformed Objection to Natural Theology p. 145. 'The dogmatic model of natural theology $\beta$ presupposes that natural theistic arguments are the product of human reason as it operates in the regenerate mind.' In other words, natural theology on the basis of faith.

49. Ibid., p. 5, cp. pp. 53, 99-101, 41-42, 55-64, 223, 26 (where the words 'function and 'model' are used for the same content). Usually Sudduth contrasts two 'models' of natural theology. His preferred model is internal to and the other is 'external to dogmatic', supernatural or revealed theology (pp. 4-5, 52-53). Once three 'functions' of natural theology are named: 'the dogmatic', 'the pre-dogmatic' and 'the apologetic'. But 'the apologetic function' appears to be reducible to, or part of, the 'dogmatic function of natural theology', since it signifies 'digressions within the dogmatic system designed to counter atheistic objections, or at any rate, designed to supply the Christian with such responses' (p. 53). Moreover, on p. 101 the two models are contrasted in terms of 'apologetics and the-predogmatic model'. Within Christian doctrine, apologetics is said to have a function to 'refute atheological objections' and remove 'important obstacles' to as well as to trigger 'theism' (pp. 141-142).

50. Ibid., p. 227.

51. Ibid., p. 155.

52. Ibid., p. 154.

53. Ibid., p. 155.

54. Ibid., p. 157.

55. Ibid., p. 159.

56. Ibid., p. 156.

57. Ibid., p. 223. Natural theology is 'driven by the same goals as dogmatic theology' (p. 227).

58. The primary source for Sudduth's dogmatic 'model' of natural theology may be what Wolterstorff describes as the neo-orthodox misunderstanding of the Augustinian motto fides quaerens intellectum 'to develop history, sociology, philosophy, political theory, and so forth, in the light of faith'. Another source may be Swinburne's Paleyian account. Cp.Wolterstorff, 'Reformed Epistemology', p. 42, Richard Swinburne, Faith and Reason, 2 ed. (Oxford: Clarendon Press, 2005), pp. 91-92, and Sudduth, The Reformed Objection to Natural Theology, p. x. 
59. Sudduth, The Reformed Objection to Natural Theology, pp. 82, 128. With the theological interests and assumptions of Sudduth one would expect him to be a bit hesitant to accommodate himself to the modern paradigm of reducing all kinds of assent to 'belief', since in his tradition to believe is only to assent to the extrinsic evidence of (human or divine) testimony. Cp. Carruthers, ed., The Westminster Confession of Faith: The Preparation and Printing of its Seven Leading Editions and a Critical Text, I.iv, x, VII. iii, XIV.ii. Faith is conceived as one of three kinds of assent expressible in statement and thus part of intellectual (as opposed to sensory) knowledge. Acts of assent are in turn specified either on account of the degree of assent or on account of the nature of the evidence. The powers of apprehension and reason assent on intrinsic evidence, whereas faith on extrinsic evidence. On this see John Owen, The Reason of Faith, The Works of John Owen, ed. William H. Goold, vol. 4, 24 vols. (London: Johnstone \& Hunter, 1850-1855, 1677), pp. 82-84, with analysis in Sebastian Rehnman, 'Graced Response: John Owen on Faith and Reason', Neue Zeitschrift für Systematische Theologie und Religionsphilosophie 53 (2011).

60. As far as I know there is no trajectory of this threefold analysis of knowledge in the primary sources of ancient, medieval and early modern philosophy. From late Antiquity to the end of the Middle Ages 'the issue was not how to define knowledge [...] but how to understand the cognitive operations that generate it.' Robert Pasnau, 'Human Nature,' Cambridge Companion to Medieval Philosophy, ed. A.S. McGrade (Cambridge: Cambridge University Press, 2003), p. 214, cp. John Marenbon, Later Medieval Philosophy (11501350): An Introduction, 2 ed. (London/New York: Routledge, 1991). (I know that there is a later edition, but this one focused on knowledge.) According to Lloyd P. Gerson, this justified-true-belief-conception of knowledge arose in the seventeenth century amidst the philosophical analysis performed in support of the new science. Lloyd P. Gerson, Ancient Epistemology (Cambridge: Cambridge University Press, 2009), p. 3. However, he does not refer to any sources and I do not know where, say, Descartes, Locke and Hume engage in this triple analysis. Compare Desmond M. Clarke, 'Descartes' Philosophy of Science and the Scientific Revolution', The Cambridge Companion to Descartes, ed. John Cottingham (Cambridge: Cambridge University Press, 1992), Wolterstorff, John Locke and the Ethics of Belief, Robert Fogelin, 'Hume's Scepticism', The Cambridge Companion to Hume, eds. David Fate Norton and Jacqueline Taylor, 2 ed. (Cambridge: Cambridge University Press, 2009), Robert McRae, 'The Theory of Knowledge', The Cambridge Companion to Leibniz, ed. Nicholas Jolley (Cambridge: Cambridge University Press, 1994), and Linda L. McAlister, 'Brentano's Epistemology', The Cambridge Companion to Brentano, ed. Dale Jacquette (Cambridge: Cambridge University Press, 2004). Thus the following common assumption is false: 'The rough consensus about the definition of knowledge that had held for over 2000 years unravelled [in 1963]. Robert C. Roberts and W. Jay Wood, Intellectual Virtues: An Essay in Regulative Epistemology (Oxford: Clarendon, 2007), p. 5. They refer to Edmund Gettier, 'Is Justified True Belief Knowledge?', Analysis 23 (1963), but he wrote of attempts in 'recent years' and refers to Ayer and Chisholm. These are also the earliest appealed to by Robert Shope, The Analysis of Knowing: A Decade of Research (Princeton: Princeton University Press, 1983), pp. 6-7. Although Ayer does not use what has become the established terminology, he claims that there are 'necessary and sufficient conditions of knowing' and that what has later come to be termed 'justification' is 'the main concern of what is called the theory of knowledge'. A.J. Ayer, The Problem of Knowledge (London: Macmillan, 1956), p. 35. In his highly 
influential introduction to epistemology, Chisholm claims to have arrived at a partial solution to the problem [of Theaetetus]'. Roderick M. Chisholm, Theory of Knowledge (Englewood Cliffs: Prentice-Hall, 1966), p. 23.

61. Not only does Socrates reject Theaetetus's attempt to define 'knowledge' in terms of 'true belief with logos' (Theaetetus, 206c-210a9), but the dialogue ends without an (explicit) alternative account (unless it is the intellectual virtues of wisdom (145d-e) and understanding (210c)). Cp. 'So it is not clear that Socrates is advancing a standard analysis of knowing. Shope, The Analysis of Knowing: A Decade of Research, p. 12, and Gerson, Ancient Epistemology, pp. 44-61.

62. This is my conclusion from the discussion in, say, Kihyeon Kim, 'Internalism and Externalism in Epistemology', American Philosophical Quarterly 30 (1993), Linda Zagzebski, 'The Inescapability of Gettier Problems', Philosophical Quarterly 44 (1994), Keith Allen Korcz, 'Recent Work on the Basing Relation', American Philosophical Quarterly 34 (1997), E. Conee and R. Feldman, 'The Generality Problem for Reliabilism', Philosophical Studies 89 (1998). Although it may be a bit of wishful thinking, 'it seems to be rapidly becoming a new orthodoxy that the whole enterprise from Descartes, Locke and Kant, and pursued by various nineteenth- and twentieth-century succession movements, was a mistake.' Charles Taylor, 'Overcoming Epistemology', After Philosophy: End or Transformation?, eds. Kenneth Baynes, James Bohman and Thomas A. McCarthy (Cambridge, Mass/London: MIT Press, 1987), p. 465.

63. 'Some will say that my talk about the concept of knowledge [Wissen] is irrelevant, since this concept as understood by philosophers, while indeed it does not agree with the concept as it is used in everyday speech, still is an important and interesting one, created by the kind of sublimation from the ordinary, rather uninteresting one. But the philosophical concept was derived from the ordinary one through all sorts of misunderstandings, and it strengthens these misunderstandings. It is in no way interesting, except as a warning.' Ludwig Wittgenstein, Remarks on the Philosophy of Psychology, trans. G.G. Luckhardt and M.A.E. Aue, eds. G. H. von Wright and Heikki Nyman, vol. 2 (Oxford: Blackwell, 1980), p. 289.

64. This would have to be further developed elsewhere on the basis of what I take to be the meaning of 'pros hen legómena', 'analogia' and 'Familienähnlichkeit' in, say, Aristotle, Ethica Nicomachea, Oxford Classical Text, ed. I. Bywater (Oxford: Clarendon Press, 1894), 1096b26-31, Aristotle, Metaphysics: A Revised Text, with Introduction and Commentary, 1003a32-b16, 30a16-27, Aquinas, Sententia libri Metaphysicae, n. 53445, 1320-38, Rudolphus Goclenius, Lexicon philosophicum (Frankfurt: Mathias Becker, 1613), pp. 96-102, Ludwig Wittgenstein, The Blue and Brown Books: Preliminary Studies for the Philosophical investigations, 2 ed. (Oxford: Blackwell, 1969), pp. 26-27, and Ludwig Wittgenstein, Philosophical Investigations, eds. P. M. S. Hacker and Joachim Schulte, 4 ed. (Oxford: Wiley-Blackwell, 2009, 1953), \$\$66-67, 164. A sadly neglected analysis is Oswald Hanfling, Philosophy and Ordinary Language: The Bent and Genius of Our Tongue (London: Routledge, 2000), pp. 94-110. That chapter was first published as a paper in 1985 .

65. Hanfling, Philosophy and Ordinary Language: The Bent and Genius of Our Tongue, p. 104, cp. J. O. Urmson, 'Prichard and Knowledge', Human Agency, Language, Duty and Value: Philosophical Essays in Honor of J. O. Urmson, eds. Jonathan Dancy, J. M. E. Moravcsik and C. C. W. Taylor (Stanford: Stanford University Press, 1988), pp. 12-20, 
and G. E. M. Anscombe, 'Knowledge and Essence', A Wittgenstein Symposium: Girona 1989, ed. Josep-Maria Terricabras (Amsterdam: Rodopi, 1993), pp. 31-32.

66. On another occasion this would have to be developed along the lines of, say, Aristotle, Physics: A Revised Text with Introduction and Commentary, 193a5-8, Aristotle, De anima: Edited with Introduction and Commentary, 418a11-17, Aristotle, Posterior Analytics: A Revised Text with Introduction and Commentary Oxford Classical Text, ed. W. D. Ross (Oxford: Clarendon Press, 1949), 72b19-23, 99b17-100b17, Aristotle, Metaphysics: A Revised Text, with Introduction and Commentary, 1005b11-12b31, Thomas Aquinas, Commentaria in octo libros Physicorum Aristotelis, Opera omnia (Romae: Ex Typographia Polyglotta, 1884, 1268-9), lib. 21.1 n. 8 (148), Thomas Aquinas, Sentencia libri De anima, Opera omnia, vol. 45/1 (Paris: Vrin, 1984, 1268), lib. 2 1. 13 n. 2-3 (384-85), Thomas Aquinas, Expositio libri Posteriorum analyticorum, Opera omnia, vol. 1*/1-2 (Paris: Vrin, 1989, 1269-72), lib. 1, lec. 7, lib. 2 lec. 20 (596-748), Aquinas, Sententia libri Metaphysicae, lib. 4 1. 6-17, Keckermann, Systema physicum, pp. 321-30, 479-83, Thomas Reid, Essays on the Intellectual Powers of Man, Thomas Reid's Inquiry and Essays, eds. Ronald E. Beanblossom and Keith Lehrer (Indianapolis: Hackett Publishing Company, 1983, 1785), Ludwig Wittgenstein, Tractatus logico-philosophicus, trans. C. K. Ogden (London: Routledge, 1922), 6.51, and Ludwig Wittgenstein, On Certainty, trans. Denis Paul and G. E. M. Anscombe, eds. G. E. M. Anscombe, G. H. von Wright and Denis Paul, Corrected ed. (Oxford: Blackwell, 1974, 1969).

67. For some historical reflections on how the history of natural theology reflects the shift from traditional realist to modern sceptical epistemology, see Webb, Studies in the history of natural theology, pp. 53-69.

68. Sudduth, The Reformed Objection to Natural Theology, pp. 210-19. Earlier (p. 194) it is claimed that some such project is also found in some nineteenth century reformed theologians.

69. The criterion of simplicity cannot be dealt with adequately here, but that it is not as unquestionable as Sudduth suggests may be seen in the following works: Robert M. Burns, 'Richard Swinburne on Simplicity in Natural Science', Heythrop Journal 40 (1999), Adolf Grünbaum, 'A New Critique of Theological Interpretations of Physical Cosmology', British Journal for the Philosophy of Science 51 (2000), Richard Swinburne, 'Reply to Grünbaum', British Journal for the Philosophy of Science 51 (2000), Adolf Grünbaum, 'The Poverty of Theistic Cosmology', British Journal for the Philosophy of Science 55 (2004), Richard Swinburne, 'Second Reply to Grünbaum', British Journal for the Philosophy of Science 56 (2005), Adolf Grünbaum, 'Rejoinder to Richard Swinburne's 'Second Reply to Grünbaum”, British Journal for the Philosophy of Science 56 (2005), Adolf Grünbaum, 'Is Simplicity Evidence of Truth?', American Philosophical Quarterly 45 (2008), Julia Göhner, Marie I. Kaiser and Christian Suhm, 'Is Simplicity an Adequate Criterion of Theory Choice?', Johannes Korbmacher, Sebastian Schmoranzer and Ansgar Seide, 'Simply False? Swinburne on Simplicity As Evidence of Truth', and Richard Swinburne, 'Reply to My Critics' (esp. pp. 189-96), all three in Richard Swinburne: Christian Philosophy in a Modern World, eds. Nicola Mossner, Sebastian Schmoranzer and Christian Weidemann (Frankfurt: Ontos Verlag, 2008).

70. Compare, for instance, Richard Swinburne, The Coherence of Theism, rev. ed. (Oxford: Clarendon Press, 1993), pp. 51-87 ('analogy' in his sense), Richard Swinburne, The Christian God (Oxford: Oxford University Press, 1994), pp. 170-91, and Richard Swinburne, Responsibility and Atonement (Oxford: Clarendon Press, 1989), pp. 137-62, 
with Hieronymus Zanchius, De natura Dei seu De divinis attributis (Neustadt: Matthias Harnisius, 1590, 1577), I.vi.x, Ix.8, IV.ii, V.ii, and Turrettini, Institutio theologicae elencticae I.ix.6, III.i.1, III.iv.1, III.vi.1, IV.i.11, III.xvi.6, III.xxv, III.xvii, IV, IX, X, XIV.x$\mathrm{xv}$, XV-XVII. A similar comparison could be made with Plantinga's anthropomorphism, semipelagianism, and Nestorianism and/or Monophysitism: Alvin Plantinga, Against Naturalism', Knowledge of God, eds. Alvin Plantinga and Michael Tooley, Great Debates in Philosophy (Oxford: Blackwell, 2008), pp. 2-4, Plantinga, The Nature of Necessity, pp. 165-93, and Alvin Plantinga, 'On Heresy, Mind, and Truth', Faith and Philosophy 16 (1999), pp. 183-87.

71. Sudduth, The Reformed Objection to Natural Theology, p. 210. Earlier (p. 172) Sudduth contrasts traditional 'logical demonstrations' in favour of contemporary 'inductive arguments', and correctly notes that the orthodox would rebut the neoorthodox claim 'by demonstrating the existence of God'. There is a similar short shrift to demonstration in Richard Swinburne, The Existence of God, 2 ed. (Oxford: Clarendon Press, 2004), pp. 6, 13.

72. This syllogism aims to summarise the convoluted formulations in Aristotle, Physics: A Revised Text with Introduction and Commentary, 241b24-42a49, 54b1758a27, and Aristotle, Metaphysics: A Revised Text, with Introduction and Commentary, 1071b3-73a13. Herein I have found the following works helpful: Hippocrates G. Apostle, Aristotle's Physics: Translated with Commentaries and Glossary (Bloomington/London: Indiana University Press, 1969), Aquinas, Commentaria in octo libros Physicorum Aristotelis, lib. 7 1. 1-2 (884-95), lib. 8 1. 7-11 (1021-68), Aquinas, Sententia libri Metaphysicae, lib. 12 1. 5-7 (2488-535), Daniel W. Graham, Aristotle Physics Book VIII: Translated with a Commentary (Oxford: Clarendon Press, 1999), Robert Wardy, The Chain of Change: A Study of Aristotle's Physics VII (Cambridge: Cambridge University Press, 1990), and Leo Elders, Aristotle's Theology: A Commentary on Book L of the Metaphysics (Assen: Van Gorcum, 1972), pp. 138-206.

A similar argument, in one of Aquinas's synopses, is of course nowadays often just analysed briefly and dismissed abruptly. The background is likely the influential but (arguably) tendentious discussion in Anthony Kenny, The Five Ways: St Thomas Aquinas' Proofs of God's Existence (London: Routledge \& Kegan Paul, 1969), pp. 6-33. For two good replies, see Lubor Velecky, Aquinas' Five Arguments in the Summa theologiae 1a, 2, 3 (Kampen: Kok, 1994), pp. 68-95, and David Oderberg, 'Whatever Is Changing is Being Changed by Something Else: A Reappraisal of Premise One of the First Way', Mind, Method, and Morality: Essays in Honour of Anthony Kenny, eds. John Cottingham and P. M. S. Hacker (Oxford: Oxford University Press, 2010).

For an early instance of an implicit reliance on Aquinas's version in the reformed Church, see Franciscus Junius, Theses theologicae Heidelbergenses, D. Francisci Junii opuscula theologica selecta, ed. Abraham Kuyper (Amsterdam: Wormser, 1882, 1592), p. 318 (theses 29-31).

73. Sudduth, The Reformed Objection to Natural Theology, p. 186.

74. Ibid., p. 101.

75. Ibid., p. 29. Later Sudduth gives the following examples of 'self-evident truths': ' $2+2=4$, and all bachelors are unmarried males' (p. 83 n. 16).

76. Although Aristotle clearly was wrong on many astronomical, biological, chemical and mechanical issues, he was right that a generic analysis of the material world is needed for specific analyses of the same (Physics, esp. I.i.). For answers to general questions about 
explanation, causality, change, time, place and chance (as well as the relation between the universal and the individual) are (more or less) implicit in particular questions about nature. Experiments suppose what matter, change, time, place and chance are. But the mathematical character of modern physical, chemical and biological experiments often attempts to bypass these generic questions. Thus a recent Nobel Laureate in physics writes about the myth of 'the idea of mastery of the universe through mathematics alone'. What is needed are 'larger conceptual issues, which are not [experimental] science but philosophy [of nature]'. Robert B. Laughlin, A Different Universe: Reinventing Physics from the Bottom Down (New York: Basic Books, 2005), pp. xv-xvi. For a similar nonreductionist view of natural science, see Franklin M. Harold, The Way of the Cell: Molecules, Organisms, and the Order of Life (Oxford: Oxford University Press, 2001). The modern experimental achievements arose of course against the astronomical, biological, chemical and mechanical inadequacies of the tradition and not against the generic account of nature.

77.'Premises have strong epistemic credentials just if they are immune from doubt, error, or revision, or they are universally held by all rational cognizers who consider and understand the premises of the argument.' Sudduth, The Reformed Objection to Natural Theology, p. 171. In this paragraph Sudduth is explicating his view of what a demonstrative argument is. This view also comes to expression elsewhere; for instance, pp. 83 and 172 .

78. This will have to suffice for now in order to avoid misunderstanding. To pursue this further one may want to start with James D. Madden, 'Aristotle, Induction, and First Principles', International Philosophical Quarterly 44 (2004), Anthony Kenny, 'Concepts, Brains, and Behaviour', Grazer Philosophische Studien 81 (2010), and David S. Oderberg, 'Concepts, Dualism, and the Human Intellect', Psycho-Physical Dualism Today: An Interdisciplinary Approach, eds. Alessandro Antonietti, Antonella Corradini and E. J. Lowe (Lanham, MD/Plymouth: Lexington Books, 2008).

79. Sudduth, The Reformed Objection to Natural Theology, pp. 204-07.

80. Cp. Aristotle, Posterior Analytics: A Revised Text with Introduction and Commentary I.xiii, and Aquinas, Expositio libri Posteriorum analyticorum, lib. 1 1. 23.

81. Cp. Aristotle, Physics: A Revised Text with Introduction and Commentary, VIII.ix-x.

82. Cp. Aristotle, Metaphysics: A Revised Text, with Introduction and Commentary, XII.

83. On the classical reformed doctrine of God, see Sebastian Rehnman, 'The Doctrine of God', Companion to Reformed Orthodoxy (16th and 17th Centuries), ed. Herman Selderhuis (Leiden: Brill, forthcoming).

84. I thank Profs. Paul Helm, Richard Muller, Daniel von Wachter, Dr. Per Landgren and my doctoral students Per Holmer, Jonatan Jäderberg and Stefan Lindholm for discussing an earlier version of this paper with me. 